Bangladesh J. Bot. 49(1): 1-11, 2020 (March)

\title{
CHEMICAL COMPOSITION, FATTY ACIDS AND OIL STABILITY OF CHROZOPHORA BROCHIANA (VIS.) SCHWEINF. SEED GERMINATION
}

\author{
Manal Abasher Ahmed, Abdalbasit Adam Mariod ${ }^{1,2 *}$ \\ Ismail Hassan Hussein ${ }^{3}$ and Bertrand Matthaus ${ }^{4}$ \\ Department of Health Education and Promotion, Faculty of Public Health and \\ Tropical Medicine, Jazan University Saudi Arabia \\ Keywords: Chrozohpora brochiana, Germination, Fatty acids, Oxidative stability
}

\begin{abstract}
The chemical composition of seeds of Chrozophora brochiana (Vis.) Schweinf. as well as stability of the oil extracted from the seeds affected by germination have been investigated. $C$. brochiana seed was found to be a rich source of oil (42.9\%) and protein (18.2\%). Seed germination increased the moisture, protein, fiber and ash contents and decreased the fat and carbohydrate contents. The fatty acid composition was also influenced by germination where linoleic and oleic acids increased and stearic acid decreased. The concentrations of $\mathrm{Na}, \mathrm{K}, \mathrm{Cu}$ and $\mathrm{Ca}$ were higher in germinated seeds. FTIR spectroscopy was utilized to screen - changes in the germinated and ungerminated seeds during the successive heating at $70^{\circ} \mathrm{C}$ for $72 \mathrm{hrs}$. It was found that the oil extracted from germinated seeds was oxidized faster than ungerminated seeds when subjected to successive heating.
\end{abstract}

\section{Introduction}

Species of Chrozophora A. Juss. (Euphobiaceae) are annual plants. Its leaves, stems and fruits are utilized in food and pharmaceuticals. Chrozophora brochiana (Vis.) Schweinf. is a shrubby monoecious herb up to $60-150 \mathrm{~cm}$ tall. The seeds are ovoid, smooth, yellowish tan, secured by a slender, pale, gleaming aril (Ahmed et al. 2014). The plant is found in Sudan (where it is known as Argassi) and other African countries, the seeds are boiled and utilized for food and the seed oil is extracted through oil mills to get clear yellow edible oil.

C. brochiana seeds contain about $26 \%$ protein and $37-40 \%$ oil composed of 11 triacylglycerols with a low melting point (Hussein et al. 2006, Mirghani et al. 1996). Seeds germinate with absorption of water and activate the reserves within their storage tissues to help seedling development, and the process is completed when the embryonic axis stretches (Bewley et al. 2001). Kuo et al. (2004) reported that, germination causes vital changes in the biochemical, nutritional and sensory characteristics of legume seeds. The process is accompanied by breakdown of seed-storage lipids and structural proteins causing an increase in the level of dietary fiber.

Fourier transform infrared spectroscopy (FTIR) has been successfully utilized to analyze vegetable oils stability (Russin et al. 2004, Rohman et al. 2011) and to study the impact of temperature on the stability of oil obtained from roasted and unroasted safflower seeds (Mariod et al. 2012a). The aim of this work was to study the impact of the germination process on the constituents of $C$. brochiana seeds and on its oil composition and stability.

\footnotetext{
*Author for correspondence: <basitmariod58@gmail.com>, <basitmariod@yahoo.com>. ${ }^{1}$ Faculty of Science and Arts-Alkamil, University of Jeddah, P.O. Box 110, Alkamil 21931, Saudi Arabia. ${ }^{2}$ Indigenous Knowledge and Heritage Center, Ghibaish College of Science \& Technology, Ghibaish, Sudan. ${ }^{3}$ Max Rubner-Institute, Department for Lipid Research, Working Group for Lipid Research, Detmold, Germany. ${ }^{4}$ NOPRI, Gezira University, P. O. Box 21 Medani, Sudan.
} 


\section{Materials and Methods}

Chrozophora. brochiana seeds were obtained from Ghibaish, Western Kordofan State, Sudan. Mature seeds were cleaned with running tap water. Dried for 2 days under shed, brought to the laboratory of Food Science and Technology Department, Sudan University of Science and Technology, Khartoum North, Sudan), and stored at $4^{\circ} \mathrm{C}$ until further investigations. Chemicals and solvents were of analytical grade, and were supplied by Merck (Darmstadt, Germany).

Seeds were germinated following the technique of Akpapunam et al. (1997). Moisture content, crude protein (Kjeldahl technique), crude fat (solvent extraction), crude fiber, and ash were determined in triplicates utilizing standard methods (AOAC 2005) and the available carbohydrate contents were calculated by difference. The oil was extracted from the pulverized seeds with $n$-hexane in a Soxhlet apparatus for 6 hrs following the AOCS method (2009). One hundred mature seeds were chosen randomly and their weight and dimensions were determined using a sensitive balance (Mettler-Toledo, Columbus, OH, USA). Hulls and kernels were weighed and the proportion of weight of the hulls and the kernel was computed. The AOCS official methods (2009) were used to examine the following physicochemical properties of $C$. brochiana seed oil: relative density (Cc 10 a - 25), refractive index (Cc 7 - 25), viscosity (Tq 1a - 64), content

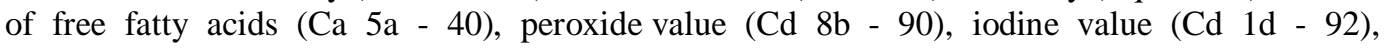
saponification value (Cd 3 - 25), and unsaponifible matter (Ca 6b - 53).

The mineral content of the $C$. brochiana seeds cake was measured following the method of the Association of Official Analytical Chemists (2005). Oil from germinated and ungerminated C. brochiana seeds were derivatized to fatty acid methyl esters (FAME) following the method of Christie (1989). FAME samples $(1 \mu \mathrm{l})$ were injected into a GC (Shimadzu, GC-2010A series; Shimadzu, Tokyo, Japan) and identified. These determinations were carried out in duplicates. The tocopherols were identified using HPLC a Merck-Hitachi low-pressure gradient system. The mobile phase used was $n$-heptane/tertiary butyl methyl ether $(99+1$, v/v) (Balz et al. 1992). These analyses were carried out in duplicates. The oil stability was measured as peroxide value following the AOCS official methods (AOCS 2009), and Fourier Transform Infrared Spectroscopy (FTIR) (Van de Voort et al. 1994). All analyses concerning the oxidative stability of oils were carried out in duplicates.

Unless otherwise stated, all experiments were carried out in triplicate and the results were expressed as means $\pm \mathrm{Sd}$. Statistical analysis was carried out using a one-way ANOVA with a significance level of $\mathrm{p} \leq 0.05$. The software used for the statistical analysis was the SPSS for Windows statistical package (v.10.0.6; SPSS, Chicago, IL, USA).

\section{Results and Discussion}

Seeds of Chrozophora brochiana resemble those of sorghum in shape and size, but they are somewhat darker in color. The average weight of 100 seeds was $3.27 \mathrm{~g}$, which was similar to that reported by Hussein et al. (2006). The weight of 100 kernels was $2.07 \mathrm{~g}$ and the weight of 100 hulls was $1.2 \mathrm{~g}$. The ratio of the hull to the kernel was $43: 57$ and the percentage of kernel in the whole seed was 63.3 while it was 36.7 of the hull.

Table 1 demonstrates the proximate composition and physicochemical properties of ungerminated and germinated $C$. brochiana seed oil. The results revealed the following percentages for moisture $(4.9 \pm 0.05)$, protein $(18.20 \pm 0.42)$, crude fiber $(21.7 \pm 0.28)$, and ash $(1.05 \pm 0.08)$ in ungerminated seeds. These values were found to be significantly affected by the germination process $(\mathrm{p} \leq 0.05)$ and were found to increase to $6.79 \pm 0.06,18.64 \pm 0.15,27.4 \pm 0.28$, and $1.9 \pm$ $0.42 \%$, respectively. On the other hand, the percentages of fat and carbohydrates before germination were $42.9 \pm 0.14$, and $11.28 \pm 0.70$, respectively, and were decreased to $37.7 \pm 0.17$ 
and $8.7 \pm 0.14$ after germination. The results showed that $C$. brochiana seed is a good source of oil $(42.9 \%)$ and protein $(18.2 \%)$, the values of protein and oil were compared favorably with those reported by Hussein et al. 2006, Mirghani et al. 1996. The protein and fat content of seeds from other plants of the same family seem to differ e.g. the undecorticated castor seeds contain $20.78 \%$ protein and 51.20\% fat (Dastagir et al. 2013), while Chrozophora tinctoria seed contain 6.8\% protein and $7.6 \%$ fat (Annongu et al. 2008).

The increase of the protein content as a result of germination, increases the nutritional value of the germinated seeds. This might be due to the net enzymatic synthesis of protein leading to the production of some amino acids during protein synthesis (Kim et al. 2012). The slight increment in protein is due to the degradation of the high molecules of protein to the simpler peptides during germination which is in agreement with the findings of Tian et al. (2010), who reported that the protein concentration of oat seeds gradually increased because of germination.

The reduction in fat and carbohydrate contents (Table 1) could be ascribed to their utilization as energy sources during the germination process. These results are in agreement with the results reported by Akpapunam et al. (1997), who reported that the process of germination reduced fat and starch contents and increased the protein and fiber content of jack beans. However, these results are in contrast with Mariod et al. (2012b), who reported that germination of black cumin seeds increased both oil and protein contents while other constituents decreased. Colmenares and Bressani (1990) reported a marked increase in moisture content during germination of amaranth species and they also reported that, protein, oil, crude fiber, and ash contents did not change significantly.

Table 1. Proximate analysis of seed and physicochemical properties of oil extracted from germinated and ungerminated Chrozophora brocchiana seeds*.

\begin{tabular}{lll}
\hline Parameters & $\begin{array}{l}\text { Ungerminated } \\
\text { seeds }(\%)\end{array}$ & $\begin{array}{l}\text { Germinated } \\
\text { seeds }(\%)\end{array}$ \\
\hline Moisture & $4.87 \pm 0.05^{\mathrm{a}}$ & $6.79 \pm 0.06^{\mathrm{b}}$ \\
Oil & $42.90 \pm 0.14^{\mathrm{a}}$ & $37.73 \pm 0.17^{\mathrm{b}}$ \\
Protein & $18.20 \pm 0.42^{\mathrm{a}}$ & $18.64 \pm 1.15^{\mathrm{a}}$ \\
Fiber & $21.70 \pm 0.28^{\mathrm{a}}$ & $27.40 \pm 0.28^{\mathrm{b}}$ \\
Ash & $1.05 \pm 0.08^{\mathrm{a}}$ & $1.92 \pm 0.42^{\mathrm{b}}$ \\
Carbohydrate & $11.28 \pm 0.70^{\mathrm{a}}$ & $7.65 \pm 0.14^{\mathrm{b}}$ \\
Refractive index, $\left(25^{\circ} \mathrm{C}\right)$ & $1.4720 \pm 0.00^{\mathrm{a}}$ & $1.4718 \pm 0.00^{\mathrm{a}}$ \\
Free fatty acid & $2.66 \pm 0.01^{\mathrm{a}}$ & $6.30 \pm 0.14^{\mathrm{b}}$ \\
Unsaponifiable matter & $0.22 \pm 0.00^{\mathrm{a}}$ & $0.40 \pm 0.00^{\mathrm{b}}$ \\
\hline
\end{tabular}

*All determinations (except RI, FFA\%, unsaponifiable and color) were carried out in triplicate and mean value \pm standard deviation $(\mathrm{Sd})$ are reported. Significant differences in a same row are shown by different letters $(\mathrm{p}<0.05)$.

Table 1 also shows that the oil extracted from the ungerminated seeds had $2.66 \%$ of free fatty acids and that this value increased to $6.3 \pm 0.14 \%$ by the germination process. The content of free fatty acids was higher compared to results of Hussein et al. (2006) who reported that freshly extracted oil from $C$. brochiana initially had a low free fatty acid value but it increased upon long storage. The unsaponifiable matter of the oil extracted from ungerminated seeds was $0.22 \%$ and 
the refractive index was 1.4720 at $25^{\circ} \mathrm{C}$, which agreed with results of Hussein et al. (2006) and is in the range found for sunflower, groundnut and soybean oils (Al-Kahtani 1983). The level of the unsaponifiable matter was different from that reported by Mirghani et al. (1996). It is also found in this experiment that the germination process caused an increase in the free fatty acids and unsaponifiable matters (to 6.3 and $0.40 \%$, respectively), while the refractive index decreased to 1.4718 .

Mineral content of ungerminated and germinated C. brochiana seeds is presented in Table 2. Potassium was the predominant element in the seeds followed by magnesium and sodium then iron, calcium, and manganese. Ungerminated seeds had a higher content (in $\mathrm{mg} / 100 \mathrm{~g}$ ) of potassium $(32.01 \pm 0.014)$, magnesium $(9.77 \pm 0.014)$ and sodium $(1.589 \pm 0.001)$, of which the levels of potassium and sodium were significantly $(\mathrm{p} \leq 0$. 05) increased by germination to $58.70 \pm$ 0.14 and $5.80 \pm 0.014$ while magnesium showed a slight decrease to $9.52 \pm 0.14$. The content of calcium, manganese, and copper increased slightly in geminated seeds, while the content of iron decreased. The zinc and cobalt content also increased during germination process. The increments in mineral concentrations are likely to be due to removal of phytate as a result of germination (Sokrab et al. 2012). Germination activates endogenous grain phytase which can degrade phytate. During germination, phytins are broken down by endogenous phytase enzymes, releasing their $\mathrm{P}$, inositol and mineral contents for use by the growing seedling (Afify et al. 2011). Phytate and polyphenols, are considered as antinutritional factors because of their interactions with food constituents such as minerals that render them unavailable for absorption by the human body. Reductions of such antinutritional factors by processing methods such as soaking, sprouting, cooking, malting, fermentation, and germination have been shown to increase the levels of ingested minerals (Steve 2012). Many authors reported increases in major and trace mineral contents, such as zinc, manganese, copper and cobalt, by germination (Sokrab et al. 2012), likely to be due to removal of phytate (Colmenares and Bressani 1990). These results are sensibly great in light of the fact that potassium assumes an essential part in human physiology, and sufficient measures of it will lessen the danger of heart stroke, while calcium assumes a vital part in building stronger, denser bones early in life and keeping bones solid and healthy later in life (DawsonHughes et al. 1997).

The fatty acid composition of oil from ungerminated and germinated $C$. brochiana seeds is shown in Table 3. The percentage of myristic (C14:0), palmitic (C16: 0), palmitoleic (C16:1), stearic $(\mathrm{C} 18: 0)$, oleic $(\mathrm{C} 18: 1)$, and linoleic $(\mathrm{C} 18: 2)$ acids in the ungermenated seeds were 0.1 , 8.2, 0.2, 16.6, 24.9 and 49.3\%, respectively, which is in good agreement with the results reported by Hussein et al. (2006) and Mirgani et al. (1996). Other plants of the same family contain higher amount of unsaturated fatty acids e.g. Caryodendron orinocense contains $75.13 \%$ linoleic acid (Mde and de Padilla 1994), while Chrozophora plicata contains 60 - 75\% linolenic and linoleic acid. During germination the content of oleic acid, and linoleic acid showed a significant increase $(\mathrm{p} \leq 0.05)$, while stearic acid showed a significant decrease.

The levels of tocopherols (vitamin E) and their changes as a result of the germination process are presented in Table 4. The amounts of these tocopherols were compared with three commercial available oils mainly used in the Sudanese diet, viz. sunflower, sesame, and groundnut oils (CODEX 1999). The total vitamin $\mathrm{E}$ contents were 87.1 and $64.3 \mathrm{mg} / 100 \mathrm{~g}$ in oil from ungerminated and germinated seeds, respectively, amounts that were within the ranges which were reported by Codex (1999) for sunflower oil (44.0 -152 mg/100 g), sesame (33.0-101 mg/100 g), and groundnut $(17.0-130 \mathrm{mg} / 100 \mathrm{~g})$ oils.

The main tocopherol of ungerminated seeds was gamma-tocopherol with $73.6 \mathrm{mg} / 100 \mathrm{~g}$, representing $84.6 \%$ of the total tocopherols, followed by beta-tocopherol with $13.5 \mathrm{mg} / 100 \mathrm{~g}$, representing $15.4 \%$ of total tocopherols. These amounts decreased during germination to 60.0 
$\mathrm{mg} / 100 \mathrm{~g}(93.3 \%)$ and $4.3 \mathrm{mg} / 100 \mathrm{~g}(6.7 \%)$, respectively. Tocopherols induce a protective effect against oxidative stress linked to metabolic syndrome and they are also essential for normal neurological function (Dias 2012).

Table 2. Minerals composition of germinated and ungerminated Chrozophora brocchiana seeds*.

\begin{tabular}{lll}
\hline Minerals & $\begin{array}{l}\text { Ungerminated seeds } \\
(\mathrm{mg} / 100 \mathrm{~g})\end{array}$ & $\begin{array}{l}\text { Germinated seeds } \\
(\mathrm{mg} / 100 \mathrm{~g})\end{array}$ \\
\hline Sodium $(\mathrm{Na})$ & $1.589 \pm 0.001^{\mathrm{a}}$ & $5.80 \pm 0.014^{\mathrm{b}}$ \\
Potassium $(\mathrm{K})$ & $32.01 \pm 0.014^{\mathrm{a}}$ & $58.70 \pm 0.14^{\mathrm{b}}$ \\
Calcium $(\mathrm{Ca})$ & $0.340 \pm 0.001^{\mathrm{a}}$ & $1.204 \pm 0.001^{\mathrm{b}}$ \\
Magnesium $(\mathrm{Mg})$ & $9.77 \pm 0.014^{\mathrm{a}}$ & $9.52 \pm 0.014^{\mathrm{a}}$ \\
Copper $(\mathrm{Cu})$ & $0.145 \pm 0.001^{\mathrm{a}}$ & $0.525 \pm 0.001^{\mathrm{b}}$ \\
Iron $(\mathrm{Fe})$ & $0.548 \pm 0.001^{\mathrm{a}}$ & $0.502 \pm 0.001^{\mathrm{a}}$ \\
Manganese $(\mathrm{Mn})$ & $0.304 \pm 0.001^{\mathrm{a}}$ & $0.312 \pm 0.001^{\mathrm{a}}$ \\
Zinc $(\mathrm{Zn})$ & $0.828 \pm 0.001^{\mathrm{a}}$ & $1.570 \pm 0.014^{\mathrm{b}}$ \\
Cobalt $(\mathrm{Co})$ & $0.018 \pm 0.001^{\mathrm{a}}$ & $0.119 \pm 0.01^{\mathrm{a}}$ \\
$(\mathrm{Pb})$ & $\operatorname{Tr}$. & $\operatorname{Tr}$. \\
$(\mathrm{Cr})$ & Tr. & Tr. \\
$(\mathrm{Cd})$ & Tr. & Tr. \\
\hline
\end{tabular}

*All determinations were carried out in duplicate and mean value $\pm \mathrm{Sd}$ were reported.

Significant differences in a same row are shown by different letters $(\mathrm{p}<0.05)$.

Table 3. Effect of germination process on fatty acid composition of Chrozophora brocchiana oil (\%).*

\begin{tabular}{lll}
\hline Fatty acids (\%) & Ungerminated seeds & Germinated seeds \\
\hline Myristic $14: 0$ & $0.1 \pm 0.11^{\mathrm{a}}$ & $0.1 \pm 0.10^{\mathrm{a}}$ \\
Palmitic $16: 0$ & $8.2 \pm 0.21^{\mathrm{a}}$ & $8.2 \pm 0.20^{\mathrm{a}}$ \\
Palmitoleic $16: 1$ & $0.2 \pm 0.10^{\mathrm{a}}$ & $0.1 \pm 0.10^{\mathrm{a}}$ \\
Stearic $18: 0$ & $16.6 \pm 0.21^{\mathrm{a}}$ & $15.8 \pm 0.22^{\mathrm{b}}$ \\
Oleic $18: 1$ & $24.9 \pm 0.31^{\mathrm{a}}$ & $25.1 \pm 0.31^{\mathrm{b}}$ \\
Linoleic $18: 2$ & $49.3 \pm 015^{\mathrm{a}}$ & $50.1 \pm 0.13^{\mathrm{b}}$ \\
Linolenic $18: 3$ & $0.5 \pm 0.2^{\mathrm{a}}$ & $0.5 \pm 0.2^{\mathrm{a}}$ \\
Gadoleic 20 : 1 & $0.1 \pm 0.1^{\mathrm{a}}$ & $0.1 \pm 0.1^{\mathrm{a}}$ \\
Saturated & 24.9 & 24.1 \\
Mono-unsaturated & 25.2 & 25.2 \\
Di-unsaturated & 49.3 & 50.1 \\
Tri-unsaturated & 00.5 & 00.5 \\
\hline
\end{tabular}

*All determinations were carried out in duplicate and mean value $\pm \mathrm{Sd}$ were reported. Significant differences in a same row are shown by different letters $(\mathrm{p}<0.05)$. 
The samples were subjected to successive heating at $70^{\circ} \mathrm{C}$ for three days and the oxidative stability was monitored using the peroxide value (Table 5) and FTIR analysis. Peroxide values (PV) of ungerminated C. brochiana oil increased gradually from $1.1 \pm 0.14$ meq $\mathrm{O}_{2} / \mathrm{kg}$ oil at the starting time to $23.2 \pm 0.14$ after 3 days of storage at $70^{\circ} \mathrm{C}$. These results are comparable to the change from $2.2 \pm 0.14$ meq $\mathrm{O}_{2} / \mathrm{kg}$ oil at the beginning to $24.2 \pm 0.14$ meq $_{2} / \mathrm{kg}$ oil after $72 \mathrm{hrs}$ of storage at $70^{\circ} \mathrm{C}$ in the oil sample from germinated seeds. The PVs in the two oils increased significantly $(\mathrm{p}<0.05)$ after $72 \mathrm{hrs}$ of storage to $23.2 \pm 0.14$ and $24.2 \pm 0.14 \mathrm{meq} \mathrm{O}_{2} / \mathrm{kg}$ oil, respectively, as incubation at $70^{\circ} \mathrm{C}$ accelerates the oxidation in the oils (Mariod et al. 2012b). Oxidative stability decreased as a result of germination; this can be explained by the decrease in some bioactive components e.g. tocopherols. This natural antioxidant plays a very important role in the oil stability. The loss of such antioxidants will decrease oil stability. Also Herchi et al. (2015) reported that germination causes a decrease in germinated flax seed oil stability.

Table 4. Tocopherol composition ( $\mathrm{mg} / 100 \mathrm{~g})$ of germinated and ungerminated Chrozophora brocchiana seed oils compared with commercial oils*.

\begin{tabular}{llllll}
\hline Tocopherols & $\begin{array}{l}\text { Ungerminated } \\
\text { seed }\end{array}$ & $\begin{array}{l}\text { Germinated } \\
\text { seed }\end{array}$ & $\begin{array}{l}\text { Sunflower } \\
\text { oil }\end{array}$ & $\begin{array}{l}\text { Sesame } \\
\text { oil }\end{array}$ & $\begin{array}{l}\text { Groundnut } \\
\text { oil }\end{array}$ \\
\hline Alpha & ND & ND & $40.3-93.5$ & ND - 0.33 & $4.9-37.3$ \\
Beta & $13.5 \pm 0.1^{\mathrm{a}}$ & $4.3 \pm 0.2^{\mathrm{b}}$ & ND -3.4 & $52.1-98.3$ & ND - 2.2 \\
Gamma & $73.6 \pm 0.4^{\mathrm{a}}$ & $60.0 \pm 0.3^{\mathrm{b}}$ & ND -0.70 & $0.4-2.1$ & $8.8-38.9$ \\
Total & 87.1 & 64.3 & $40.3-97.6$ & $52.5-100.73$ & $13.7-78.4$ \\
\hline
\end{tabular}

*Values for sunflower, sesame, and groundnut oils were from the Codex Standard 210 - 1999. All determinations were carried out in duplicate and mean values were reported. Significant differences in a same row are shown by different letters $(\mathrm{p}<0.05)$. ND $=$ Non-detectable, defined as $\mathrm{p} \leq 0.05 \mathrm{mg} / 100 \mathrm{~g}$.

Table 5. Peroxide value of oil extracted from germinated and ungerminated Chrozophora brocchiana seeds and stored for 0 - 72 hrs under oxidative conditions*.

\begin{tabular}{lllllll}
\hline Samples & $0 \mathrm{hr}$ & $6 \mathrm{hrs}$ & $12 \mathrm{hrs}$ & $24 \mathrm{hrs}$ & $28 \mathrm{hrs}$ & $72 \mathrm{hrs}$ \\
\hline Ungerminated & $1.1 \pm 0.14^{\mathrm{a}}$ & $2.2 \pm 0.14^{\mathrm{a}}$ & $3.6 \pm 0.14^{\mathrm{a}}$ & $10.1 \pm 0.21^{\mathrm{a}}$ & $17.7 \pm 0.14^{\mathrm{a}}$ & $23.0 \pm 0.14^{\mathrm{a}}$ \\
Germinated & $2.2 \pm 0.14^{\mathrm{b}}$ & $2.9 \pm 0.07^{\mathrm{a}}$ & $3.9 \pm 0.14^{\mathrm{a}}$ & $12.2 \pm 0.14^{\mathrm{b}}$ & $22.9 \pm 0.14^{\mathrm{b}}$ & $24.2 \pm 0.14^{\mathrm{b}}$ \\
\hline
\end{tabular}

*All determinations were carried out in triplicate and mean values were reported. Significant differences in a same column are shown by different letters $(\mathrm{p}<0.05)$.

Fig. 1 shows the FTIR spectra of the fresh oils extracted from germinated (A) and ungerminated (B) seeds of C. brochiana. The prevailing groups in these oils are the same as in other edible oils. Fourteen visible peaks were observed in ungerminated C. brochiana seed oil at frequencies of $3473,3008,2923,2854,2677,1745,1649,1463,1377,1236,1163,1099,914$, and $723 / \mathrm{cm}$. Henna and Tan (2009) reported that absorption peaks at $3600-2800$ and $1800-700 / \mathrm{cm}$ are the dominant bands in vegetable oils. Comparison of the results of germinated seed oils with those of oils from ungerminated seeds reveals several changes in the peak intensities (absorbances). For example, (i) the band at frequency $723 / \mathrm{cm}$, associated to bending of $-(\mathrm{CH} 2)$ $\mathrm{n}-, \mathrm{HC}=\mathrm{CH}-$ (cis) (Henna and Tan 2009), was changed to $721 / \mathrm{cm}$ and its intensity was increased to 56 , (ii) the band near $1163 / \mathrm{cm}$ experienced an increased in wave number and intensity and gave 
a broad band as affected by germination, while (iii) the band near $1236 / \mathrm{cm}$ disappeared as a result of germination (Fig. 1).

Fig. 2 shows FTIR spectra of the oil extracted from germinated and ungerminated $C$. brochiana seeds stored at $70^{\circ} \mathrm{C}$ for $24 \mathrm{hrs}$. The peak intensities of oil extracted from ungerminated seeds changed in comparison with oil extracted from germinated seeds. An increase in the band absorbing at 3473 , corresponding to an increase in the concentration of hydroperoxides as a consequence of oxidation of the oil extracted from germinated seeds is quite clear. Upon progressive heating, increments in absorbances of bands corresponding to carbonylic compounds such as aldehydes, esters, ketones, and lactones should be evident (Rohman et al. 2011).
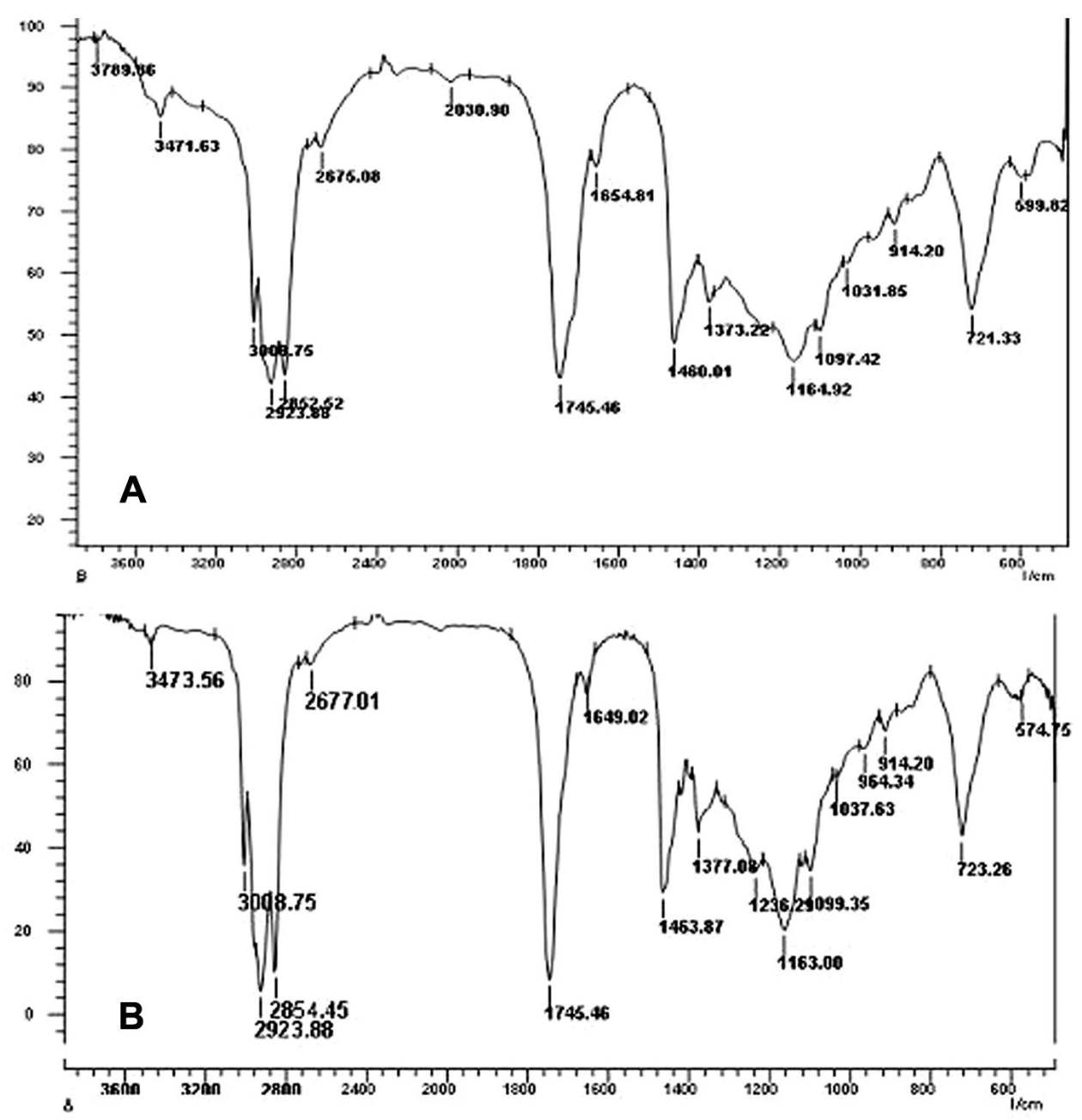

Fig. 1. FTIR spectra of oil extracted from germinated (A) and ungerminated (B) C. brocchiana seeds storaged at $70^{\circ} \mathrm{C}$ for zero hr.

Fig. 3 shows the FTIR spectra of oils extracted from germinated and ungerminated $C$. brochiana seeds incubated at $70^{\circ} \mathrm{C}$ for $72 \mathrm{hrs}$. Fourteen peaks were visible at the above mentioned 
frequencies $(3473,3008,2923,2854,2678,2028,1745,1654,1460,1373,1164,1099,914$, and $723 / \mathrm{cm}$ ). After $72 \mathrm{hrs}$ of incubation, there were sharp changes in the intensities (absorbances) of other peaks such as the peak at $1164 / \mathrm{cm}$ corresponding to the $-\mathrm{C}-\mathrm{O},-\mathrm{CH} 2-$ of extending vibration and the band at $1745 / \mathrm{cm}$ related to $\mathrm{C}=\mathrm{O}$ of extending vibration, for which the intensity is influenced by germination and by progressive storage at $70^{\circ} \mathrm{C}$. The absorbance in the region $2800-3200 / \mathrm{cm}$ was expanded showing that the bands 2854,2923 and $3008 / \mathrm{cm}$ accomplished a sharp increase in intensity. The band at $3008 / \mathrm{cm}$ was related to the extending vibration of the $\mathrm{CH}$ groups of cis double-bonds while the other two bands indicated stretching vibration of carboncarbon double bonds. Hence, the progression of oxidation was accompanied by reduction in the number of cis double-bonds and a decline in the degree of unsaturation. Germination caused a more adverse influence on the oxidative stability of the oil extracted from germinated Chrozohpora brochiana seeds as indicated by changes in the intensities and absorbance of most bands (Figs 1-3).

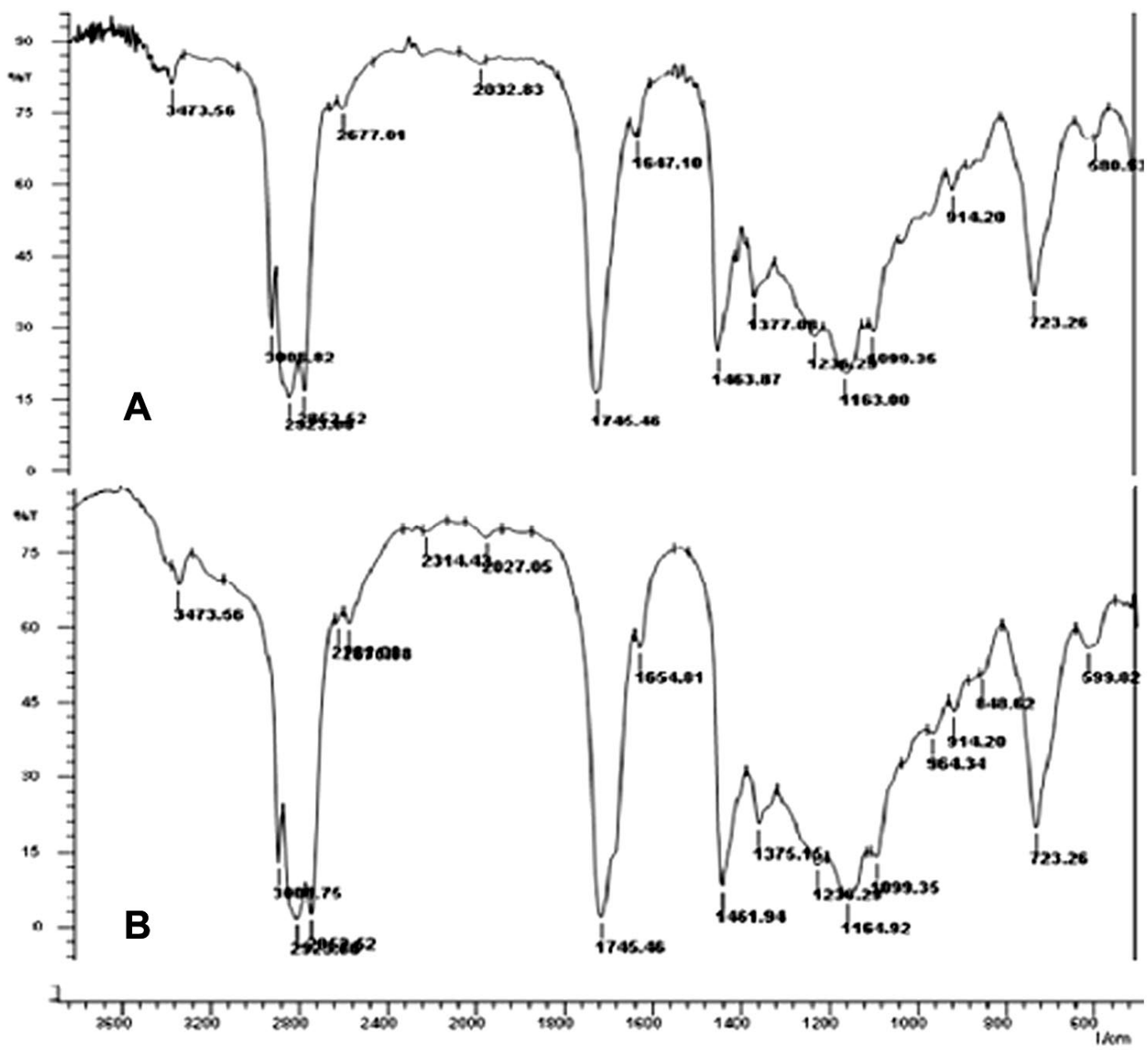

Fig. 2. Fourier transform infrared spectra of oil extracted from germinated (A) and ungerminated (B)

C. brocchiana seeds storaged at $70^{\circ} \mathrm{C}$ for $24 \mathrm{hrs}$. 


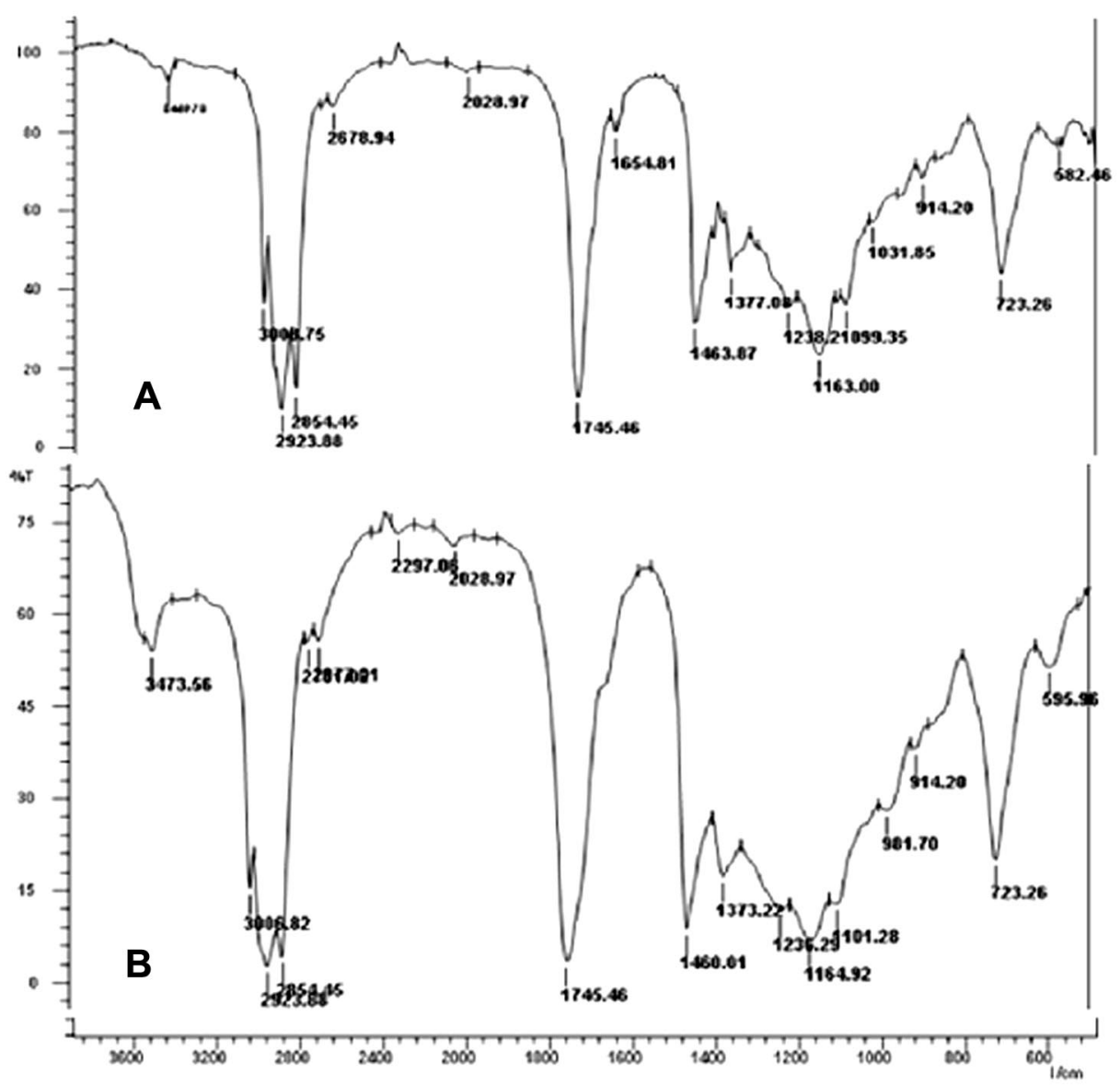

Fig. 3. Fourier transform infrared spectra of oil extracted from germinated (A) and ungerminated (B) C. brocchiana seeds storaged at $70^{\circ} \mathrm{C}$ for $72 \mathrm{hrs}$.

The results demonstrated that Chrozophora brochiana seeds contain high amounts of protein, oil, and carbohydrates. The results also show a potential for utilization as new source for vegetable oil high of unsaturated fatty acids, especially linoleic acid. It was observed that germination prompted increments in moisture and fiber and a decrease in fat and carbohydrates. Germination of the seeds increased the availability of minerals such as sodium, potassium or zinc, but the overall quality of the seed oil decreased. The content of tocopherols was remarkable lower in oil from germinated seeds and successive heating at $70^{\circ} \mathrm{C}$ resulted in a lower stability of oil from germinated $C$. brocchiana seed oils. Through FTIR, which appears suitable for studying the oxidative stability of this oil, the degree of oil oxidation was found to be lower in ungerminated than in germinated $C$. brocchiana seed oils.

\section{Acknowledgements}

The first author (AAM) acknowledges the financial support provided by the Ministry of High Education and Scientific Research, Khartoum, Sudan. 


\section{References}

Afify AE - MMR, El - Beltagi HS, Abd El - Salam SM and Omran AA 2011. Bioavailability of iron, zinc, phytate and phytase activity during soaking and germination of white sorghum varieties. PLoS ONE 6 : e25512.1.

Ahmed MA, Mariod AA, Hussein IH and Kamal-eldin A 2014. Review: Biochemical composition and medicinal uses of Chrozophora genus. Inter. J. Pharm. Rev. Res. 4: 227-232.

Akpapunam MA and Sefa-Dedeh S 1997. Some physicochemical properties and anti-nutritional factors of raw, cooked and germinated jack bean (Canavalia ensijbrmis). Food Chem. 59: 121-125.

Al-Kahtani HA 1983. Quality of soybeans and their crude oils in Saudi Arabia. J. Amer. Oil Chem. Soc. 66: 109-113.

AOCS 2009. Official methods and recommended practices of the AOCS, 6th edn. American Oil Chemists' Society, Champaign, IL C. Method Aa 4-38.

AOAC 2005. Association of Official Analytical Chemists Inc, Arlington, VA, USA. Method 935.14 and 992.24.

Balz M, Shulte E and Their HP 1992. Trennung von tocopherol und tocotrienolen durch HPLC. Fat Sci. Tech. 94: 209-213.

Bewley JD, Hempel FD, McCormick S and Zambryski P 2001. Reproductive development. In: Buchanan BB, Gruissem W, and Jones RL (Eds.), Biochemistry and molecular biology of plants, pp. 988-1043, Rockville, MD: Courier Companies, Inc.

Christie W 1989. Gas Chromatography and Lipids: A Practical Guide. Ayr, Scotland: The Oily Press Ltd. pp 50-53.

Codex Standard for named vegetable oils CODEX-STAN 210-1999.

Colmenares De Ruiz AS and Bressani R 1990. Effect of germination on the chemical composition and nutritive value of Amaranth grain. Cereal Chem. 67: 519-522.

Dastagir G, Hussain F, Khattak F and Zadi K 2013. Proximate analysis of plants of family Zygophyllaceae and Euphorbiaceae during winter. Sarhad J. Agric. 29: 395-400.

Dawson-Hughes B, Harris SS, Krall EA and Dallal GE 1997. Effect of calcium and vitamin D supplementation on bone density in men and women 65 years of age or older. New England J. Medic. 337: 670.

Dias JS 2012. Major classes of phytonutriceuticals in vegetables and health benefits: A review. J. Nutr. Ther. 1: 31 .

Henna Lu FS and Tan PP 2009. A comparative study of storage stability in virgin coconut oil and extra virgin olive oil upon thermal treatment. Inter. Food Res. J. 16: 343.

Herchi W, Bahashwan S, Sebei K, Ben SH, Kallel H and Boukhchina S 2015. Effects of germination on chemical composition and antioxidant activity of flax seed (Linum usitatissimum L.) oil. Grasas Aceites 66: 1.

Hussein IH, Mirghani MES and CheMan YB 2006. Physicochemical characteristics of Argassi (Chrozophora brocchiana), Kenaf (Hibiscus cannabinus) and Loofah (Luffa cylindrica) seed oils. Sudan J. Agric. Res. 6: $53-60$.

Kim HY, Hwang IG, Kim TM, Wood KS, Park DS, Kim JH, Kim DJ, Lee J, Lee YR and Jeong HS 2012. Chemical and functional components in different parts of rough rice (Oryza sativa L.) before and after germination. Food Chem. 134: 288-293.

Kuo YH, Rozan P, Lambein F, Frias J and Vidal-Valverde C 2004. Effects of different germination conditions on the contents of free protein and non-protein amino acids of commercial legumes. Food Chem. 86: 537-545.

Mariod AA, Ahmed SY, Abdelwahab SI, Cheng SF, Eltom AM, Yagoub SO and Gouk SW 2012a. Effects of roasting and boiling on the chemical composition, amino acids and oil stability of safflower seeds. Inter. Food Sci. Tech. 47: 1737-1743.

Mariod AA, Edris YA, Cheng SF and Abdelwahab SI 2012b. Effect of germination periods and conditions on chemical composition, fatty acids and amino acids of two black cumin seeds. ACTA Scien. Polon. Technol. Alimen. 11(4): 401-410. 
Mde JA, and de Padilla FC 1994. Physico-chemical characteristics of the Barinas nut (Caryodendron orinocense Karst. Euphorbiaceae) crude oil. Arch. Latino. Nutr. 44: 172.

Mirghani MES, Hussein IH, Dagne E and Bekele T 1996. A comparative study of seed oils of Chrozophora brocchiana and Guizotia abyssinica. Bull. Chem. Soc. Ethiopia 10:161-164.

Rohman A, Che Man YB, Ismail A and Hashim P 2011. Monitoring the oxidative stability of virgin coconut oil during oven test using chemical indexes and FTIR spectroscopy. Inter. Food Res. J. 18: 303-310

Russin TA, van de Voort FR and Sedman J 2004. Rapid determination of oxidative stability of edible oils by FTIR spectroscopy using disposable IR cards. J. Am. Oil Chem. Soc. 81: 111-116.

Sokrab AM, Ahmed IAM and Babiker EE 2012. Effect of germination on antinutritional factors, total, and extractable minerals of high and low phytate corn (Zea mays L.) genotypes. J. Saudi Soc. Agric. Sci. 11: 123.

Steve IO 2012. Influence of germination and fermentation on chemical composition, protein quality and physical properties of wheat flour (Triticum aestivum). J. Cereals Oil Seeds 3: 35.

Tian B, Xie B, Shi J, Wu J, Cai Y, Xu T, Xue S and Deng Q 2010. Physicochemical changes of oat seeds during germination. Food Chem. 119: 1195-1200.

Van de Voort FR, Ismail AA, Sedman J and Emo G 1994. Monitoring the oxidation of edible oils by Fourier transforms infrared spectroscopy. J. Am. Oil Chem. Soc. 71: 243-253.

(Manuscript received on 14 October, 2017; revised on 27 June, 2019) 